\title{
СТРАТЕГІЧНІ ОСНОВИ ДИСТАНЦІЙНОГО ОЦІНЮВАННЯ СТАНУ ПАЦІЄНТІВ У МОБІЛЬНІЙ МЕДИЦИНІ. ІНФОРМАТИВНІСТЬ, ТОЧНІСТЬ, НАДІЙНІСТЬ
}

Я. О. Шевченко

\author{
Національна медична академія післядипломної освіти імені П. Л. Шупика
}

\begin{abstract}
Проаналізовано принципи дистанційного оцінювання стану пацієнтів у мобільній медицині. Особлива увага приділена значенню інорормативності та точності показників, що вимірюються на відстані. Обґрунтовано методологію визначення інтегральної валідності отриманих кількісних оцінок дистанційного моніторингу. Зроблено висновки про необхідність використання показників ризику прогнозованих станів як універсального методу для визначення інфрормативності симптомів при мобільному спостереженні за пацієнтами. Запропоновано новий підхід підвищення точності та надійності показників при дистанційному спостереженні за станом пацієнта, пов'язаний із використанням динамічних оцінок змін.
\end{abstract}

Ключові слова: дистанційний моніторинг пацієнтів; безконтактні методи збору інфрормації; метод Байєса; інсрормативність, надійність, валідність показників.

\section{STRATEGIC BASIS OF THE REMOTE EVALUATION OF PATIENTS IN MOBILE MEDICINE. INFORMATION, ACCURACY, RELIABILITY}

Ya. O. Shevchenko

\author{
Shupyk National Medical Academy of Postgraduate Education
}

Background. The principles of remote assessment of patients in mobile medicine are analyzed. Particular attention is paid to the importance of informativeness and accuracy of indicators measured at a distance.

Materials and methods. Results. The methodology of determining the integrated validity of the obtained quantitative estimates of remote monitoring is substantiated. Conclusions are made about the need to use risk indicators of predicted conditions as a universal method for determining the informativeness of symptoms in mobile monitoring of patients.

Conclusion. A new approach to improving the accuracy and reliability of indicators in remote monitoring of the patient's condition, associated with the use of dynamic estimates of changes.

Key words: remote monitoring of patients; contactless methods of information collection; Bayesian method; informativeness, reliability, validity of indicators.

\section{СТРАТЕГИЧЕСКИЕ ОСНОВЫ ДИСТАНЦИОННОЙ ОЦЕНКИ СОСТОЯНИЯ ПАЦИЕНТОВ В МОБИЛЬНОЙ МЕДИЦИНЕ. ИНФОРМАТИВНОСТЬ, ТОЧНОСТЬ, НАДЕЖНОСТЬ}

Я. А. Шевченко

Национальная медицинская академия последипломного образования имени П. Л. Шупика

\begin{abstract}
Проанализированы принципы дистанционной оценки состояния пациентов в мобильной медицине. Особое внимание уделено значению информативности и точности показателей, измеряемых на расстоянии. Обоснованно методологию определения интегральной валидности полученных количественных оценок дистанционного мониторинга. Сделаны выводы о необходимости использования показателей риска прогнозируемых состояний как универсального метода для определения инорормативности симптомов при мобильном наблюдении за пациентами. Предложен новый подход повышения точности и надежности показателей при дистанционном наблюдении за состоянием пациента, связанный с использованием динамических оценок изменений.
\end{abstract}

Ключевые слова: дистанционный мониторинг пациентов; бесконтактные методы сбора инсрормации; метод Байеса; информативность, надежность, валидность показателей. 
Вступ. Системи дистанційного моніторингу стану пацієнтів призначені для отримання від них ряду фізіологічних даних. Найпоширенішими даними є електрокардіограма (ЕКГ), електроенцефалограма (ЕЕГ), частота серцевих скорочень i дихання, об’єм кисню в крові або пульсоксиметр, сигнали від нервової системи, артеріальний тиск, температура тіла/шкіри і рівень глюкози в крові. Крім того, іноді збираються дані про вагу пацієнта, рівні його активності та в стані сну.

Традиційні системи збирають дані за допомогою датчиків, прикріплених до тіла. Але ці системи створюють труднощі з точки зору мобільності для пацієнта та його діяльності в повсякденному житті. Оскільки такого роду пристрої впливають на комфорт пацієнта, чутливі фізіологічні дані отримують сторонній вплив. Таким чином, ця інформація може представляти не реальну хворобу пацієнта, а скоріше показники дискомфорту, що пацієнт (особливо літній пацієнт) відчуває під час фізіологічних досліджень. 3 метою усунення таких незручностей протягом останніх декількох років активно вивчаються безконтактні методи. Але до останнього часу залишаються питання про інформативність, надійність та точність показників, що отримуються при дистанційному моніторингу стану пацієнта. В літературі немає достатньої кількості кількісних оцінок валідності безперервного моніторингу життєво важливих показників.

Мета роботи: обгрунтувати методологію визначення інтегральної валідності отриманих кількісних оцінок дистанційного моніторингу.

Результати та їх обговорення. Найбільші труднощі в оцінюванні стану пацієнта представляє саме оцінювання інформативності отриманої інформації. Зазвичай, розглядається міра цінності симптому для діагностики окремого захворювання чи стану пацієнта. Симптоми можуть бути досить корисними для діагностики одних захворювань i даремними для інших. Ролі симптому в класі явищ, вочевидь, необхідна інтегральна міра для з'ясування загальної діагностичної цінності симптому. Міра діагностичної цінності симптому для класу різноманітних станів пацієнта має дорівнювати математичному очікуванню мір діагностичної цінності симптому для окремих станів. Але інформативність дослідження залежить від його місця в діагностичному процесі. Зазначена залежність «діє» через ймовірності діагнозів, обчислених на підставі даних попередніх досліджень. Ці ж ймовірності служать апріорними для обчислення можливостей діагнозів після одержання результатів чергового обстеження. Тому бажано користуватися оцінками інформативності, що не залежать від апріорного розподілу. Виходячи з цього, пропонується використання показників ризику стану (чи переходу в інший стан із більш високими характеристиками ризику) як універсального методу визначення інформативності симптомів.

Дещо простішою $є$ ситуація 3 показниками точності та надійності. Алгоритми, що використовуються в патч-пристроях, суттєво відбраковують фізіологічні сигнали, перекручені значними джерелами шуму, властивого амбулаторному характеру бездротового моніторингу. Проте ймовірність отримання артефактів залишається досить великою. Тому нами запропонований підхід підвищення точності, пов'язаний із використанням динамічних оцінок змін. Всі випадки, в яких дисперсійні показники динамічного ряду перевищують індивідуальні характеристики розкиду, підлягають додатковому аналізу та тимчасово не використовуються для прийняття рішень. Математичні підходи для підвищення точності даних, що отримуються під час дистанційних спостережень за пацієнтом використовуються й в інших дослідженнях. Так, в роботі використовується байєсівський аналіз точок зміни для виявлення східчастих змін температури в великій популяції досліджень.

Висновки. 1. Запропоновано використовувати показники ризику прогнозованих станів як універсального методу для визначення інформативності симптомів при мобільному спостереженні за пацієнтами.

2. Запропоновано новий підхід підвищення точності та надійності показників при дистанційному спостереженні за станом пацієнта, пов'язаний із використанням динамічних оцінок змін. 


\section{Література.}

1. Reliability of a wearable wireless patch for continuous remote monitoring of vital signs in patients recovering from major surgery: a clinical validation study from the TRaCINg trial / Downey, CL, Ng S, Jayne DG, Wong D. // BMJ Open. — 2019. — Режим доступу: https:// doi.org/10.1136/bmjopen-2019-031150.

2. Reliability of wireless monitoring using a wearable patch sensor in high-risk surgical patients at a stepdown unit in the Netherlands: a clinical validation study / Breteler M., Huizinga E., van Loon K. et al. // BMJ Open. - 2018. - Режим доступу: 10.1136/ bmjopen-2017-020162.

3. Accuracy of peripheral thermometers for estimating temperature: a systematic review and meta-analysis / Niven D. J., Gaudet J. E., Laupland K. B. et al. // Ann Intern Med. — 2015. — № 163. - P. 768-777.

4. A large-scale clinical validation of an integrated monitoring system in the emergency department / Clifton D. A., Wong D., Clifton L. et al. // IEEE J Biomed Health Inform. — 2013. — № 17. — P. 835-842.

\section{References.}

1. Downey, C. L., Ng S., Jayne, D. G., Wong, D. (2019). Reliability of a wearable wireless patch for continuous remote monitoring of vital signs in patients recovering from major surgery: a clinical validation study from the TRaCINg trial. BMJ Open. URL: https://doi. org/10.1136/bmjopen-2019-031150.

2. Breteler, M., Huizinga, E., van Loon, K. et al. (2018). Reliability of wireless monitoring using a wearable patch sensor in high-risk surgical patients at a step-down unit in the Netherlands: a clinical validation study. BMJ Open. URL: 10.1136/ bmjopen-2017-020162.

3. Niven, D. J., Gaudet, J. E., Laupland, K. B. et al. (2015). Accuracy of peripheral thermometers for estimating temperature: a systematic review and meta-analysis. Ann Intern Med, 163, 768-77.

4. Clifton, D. A., Wong, D., Clifton, L. et al. (2013). A largescale clinical validation of an integrated monitoring system in the emergency department. IEEE J Biomed Health Inform., 17, 835-42. 